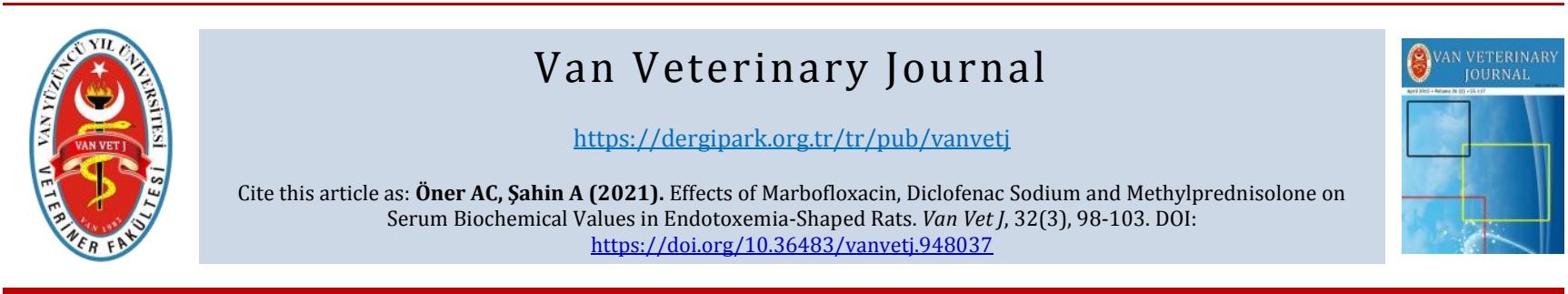

ISSN: 2149-3359

Original Article

e-ISSN: 2149-8644

\title{
Endotoksemi Şekillendirilmiş Ratlarda Marbofloksasin, Diklofenak Sodyum ve Metilprednizolonun Serum Biyokimyasal Değerler Üzerine Etkisi
}

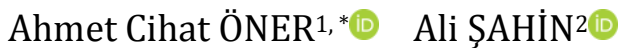 \\ ${ }^{1}$ Van Yüzüncü Yll University, Faculty of Veterinary Medicine, Department of Pharmacology and Toxicology, 65080, Van, Turkey \\ ${ }^{2}$ Karamanoğlu Mehmet Bey University, Faculty of Health Sciences, Department of Nursing, 70100, Karaman, Turkey
}

Received: 04.06.2021

Accepted: 15.10 .2021

ÖZ

\begin{abstract}
Escherichia coli'den türetilen lipopolisakkarit (LPS), sepsis ve septik şok için bir model olarak yaygın olarak kullanılmıștır. Çalışmamızda LPS ile deneysel endotoksemi oluşturulan ratlarda, marbofloksasin, diklofenak sodyum, metilprednizolon kullanılarak, bu ilaçların organ yetmezliğinin indirekt belirteçleri olan alkalen fosfotaz (ALP), alanin aminotransferaz (ALT), aspartat aminotransferaz (AST), gama glutamil transferaz (GGT), kan üre azot (BUN), kreatinin değerleri üzerine olan etkilerinin değerlendirilmesi amaçlanmıştır. Çalışma için gerekli 186 adet rat, 5 gruba ayrıldı. Kontrol grubundan 0. saatte kan örnekleri alındı. Ratlarda endotoksemi oluşturmak amacı ile intraperitoneal (IP) yolla LPS (4mg/rat) uygulandı. Gelişen endotoksemiyi tedavi etmek için marbofloksasin IP yolla $100 \mathrm{mg} / \mathrm{kg}$, diklofenak sodyum IP yolla $10 \mathrm{mg} / \mathrm{kg}$, metilprednizolon IP yolla $10 \mathrm{mg} / \mathrm{kg}$ dozunda uyguland. Daha sonra 1, 2, 4, 8, 12 ve 24. saatlerde tiyopental anestezisi altında kan örnekleri alınarak biyokimyasal değerler ölçüldü. Çalışmada serum ALP, ALT, AST, GGT, BUN ve kreatinin düzeylerinin LPS uygulaması ile arttığı $(\mathrm{P}<0.05)$ ve sepsiste beklenilen etkinin şekillendiği tespit edildi. Sepsis tedavisinde, metilprednizolon dışında diğer ilaçların tek başlarına kullanılamayacağı ancak kombine uygulamanın tercih edilebileceği sonucuna ulaşıldı.
\end{abstract}

Anahtar Kelimeler: Diklofenak sodyum, Endotoksemi, Metilprednizolon.

\section{ABSTRACT Effects of Marbofloxacin, Diclofenac Sodium and Methylprednisolone on Serum Biochemical Values in Endotoxemia-Shaped Rats}

Escherichia coli-derived lipopolysaccharide (LPS) has been used extensively as a model for septic shock and sepsis. In our study, it was aimed to induce experimental endotoxemia in rats by using LPS and the effects of marbofloxacin, diclofenac sodium and methylprednisolone on alkaline phosphatase (ALP), alanine aminotransferase (ALT), aspartate aminotransferase (AST), gamma glutamyl transferase (GGT), blood urea nitrogen (BUN), creatinine, which are indirect indicators of organ insufficiency, were assessed. 186 rats were divided into 5 groups. Blood samples were obtained from control group at $0 \mathrm{~h}$. To shape endotoxemia, LPS was administered at a dose of $4 \mathrm{mg} / \mathrm{rat}$ via intraperitonally (IP). Marbofloxacin (100 mg/kg, IP), diclofenac sodium $(10 \mathrm{mg} / \mathrm{kg}$, IP) and metylprednisolone $(10 \mathrm{mg} / \mathrm{kg}$, IP) were administered at dosage for the treatment of developing endotoxemia. Blood samples were collected under thiopental anesthesia at 1, 2, 4, 8, 12 and 24 h. They were analyzed biochemical levels. In the study, it was determined that serum ALP, ALT, AST, GGT, BUN and creatinine levels increased with LPS application $(\mathrm{P}<0.05)$ and the expected effect in sepsis was formed. As a result, LPS administration caused sepsis and it had several effects observed in the kidney and liver. It was concluded that in the treatment of sepsis, drugs other than methylprednisolone cannot be used alone, but combined application can be preferred.

Keywords: Diclofenac sodium, Endotoxemia, Methylprednisolone.

\section{Gíriș}

Dolaşımda endotoksin bulunmasına endotoksemi ismi verilir. $\mathrm{Bu}$ endotoksinler gram negatif bakterilerin veya gram negatif enterik bakterilerin hücre duvarı bileşeni olan lipopolisakkaritlerin (LPS) intestinal mukozal bariyeri aşması sonucu açığa çıkmaktadır (Hart ve MacKay 2015).
Meydana gelen olgu öncelikle sistemik inflamatuvar yanıt sendromu (SIRS), sepsis ve septik şok olarak gelişir. Yeni doğan çiftlik hayvanlarında septisemi genellikle önemli morbitite ve mortalite nedenleri olan Escherichia coli ve Salmonella spp. ile ilişkilidir. E. coli, septisemik buzağılarda en sık kan dolaşımından izole edilen bir bakteridir, ancak septisemik buzağıların\%10'unda gram pozitif bakteri 
ve\%28'inde polimikrobiyal enfeksiyon saptanmıștır (Constable ve ark. 2017, Bonelli ve ark. 2018; Pardon ve Perez 2018).

Bakterilerin toksinlerine karşı gelişen hücresel immun cevap, normal koşullarda konağ koruyabilirken hücresel cevabın aşırı tepkisi konak için olumsuz sonuçlar doğurabilmektedir. Bu nedenle sepsisin patogenezi, proinflamatuvar ve antiinflamatuvar eşitsizlik sendromu olarak ta tanımlanabilmektedir. Proinflamatuvar ve antiinflamatuvar dengenin bozulmasının konağa zarar verdiği düşünülmektedir (Camcioğlu ve Aytaç 2007; Boscolo ve ark. 2008).

Başarılı sepsis tedavisi, intravenöz olarak uygulanan geniş spektrumlu, bakterisidal bir ilaçla tedavinin hızlı bir şekilde başlatılmasını gerektirir (Pardon ve Perez 2018). Sepsis/endotoksemi ve bunlara bağlı şok olgularının tedavisinde, çeşitli ilaçlar/ajanlar denenmiştir. Son 20 yıl içerisinde de sepsisin fizyopatolojisi üzerinde araştırmalar yoğunlașmıș, buna bağlı olarak çeșitli ilaç kombinasyonları denenmiştir. Son yıllarda yapılan deneysel araştırmalarda antibiyotik, glukokortikoid, nonsteroid antiinflamatuvar ilaç (NSAID) veya kombinasyon (antibiyotik + glukokortikoid + NSAID) uygulamalarının olumlu sonuçları belirlenmiștir (Elmas ve ark. 2008, Yazar ve ark. 2009; Yazar ve ark. 2010).

Sepsis çalışmalarında en sık denenen ve sahada bu olgularda en çok kullanılan antibiyotiklerden olan florokinolonlar bakterilerde DNA-jirazın etkinliğini engelleyerek etkinlik gösteren geniş etki spektrumlu antibiyotiklerdir. Florokinolonlar, özellikle gram (-) bakteriler ve Staphylococcus türlerine karşı etki etmektedir (Traş ve ark. 2007; Yazar ve ark. 2009).

Non-steroid antiinflamatuar ilaçlar (NSAID) NF-KB'nin etkinliğini engelleyerek, proinflamatuar sitokinler, iNOS ve COX oluşumunu engeller (Meduri 1999; Yazar ve ark. 2009). Bu bilinen etkileri düșünülerek çalıșmalar gerçekleştirilse de sepsiste kullanılması hekimler arasında tartışmalı bir konu olarak karşımıza çıkmaktadır.

Deneysel septik şok modellerinde glukokortikoid uygulamalarının her zaman olumlu etkileri bildirilmiștir (Traş ve ark. 2007; Yazar ve ark. 2009). Sepsis tedavisi için glukokortikoidlerin kullanımında doz ve sağkalım oranının lineer doğrultuda olduğu saptanmıștır. $\mathrm{Bu}$ da glukokortikoidlerin kullanımının sepsis süresince doza bağıml olduğunu göstermektedir (Minneci ve ark. 2004; Yarema ve Yost 2011).

$\mathrm{Bu}$ çalışmada LPS ile deneysel endotoksemi oluşturulan ratlarda, florokinolon grubu antibiyotiklerden marbofloksasin (MAR), NASID grubundan diklofenak sodyum (DS) ve glukokortikoid grubu ilaçlardan metilprednizolonun (MPRED) tek veya kombine kullanımlarının biyokimmyasal parametreler üzerine olası etkilerinin değerlendirilmesi amaçlanmıștır.

\section{MATERYAL VE METOT}

Araștırmada Sprague - Dawley ırkı ratlardan 93 erkek, 93 dişi, her bir grupta 6 denek olmak üzere, toplam 186 adet rat kullanıldı. Deney hayvanları Van Yüzüncü Yıl Üniversitesi Tıp Fakültesi Deney Hayvanları Ünitesi'nden temin edildi. Çalıșma Selçuk Üniversitesi Veteriner Fakültesi Etik Kurulu tarafından alınan karar ile 11.04.2012 tarih ve 2012/35 numaralı izinle yürütüldü.

Biyokimyasal ölçümler için, AST kiti (IL Test AST, Milano, İtalya), ALT kiti (IL Test ALT, Milano, İtalya), ALP kiti (IL Test ALP, Milano, İtalya), BUN kiti (IL Test BUN, Milano,
İtalya), kreatinin kiti (IL Test Creatinine, Milano, İtalya) kullanıldı.

Çalışmada 0.saat olarak ayrılan hayvanlar hiçbir ilaç uygulaması yapılmadan kontrol grubu olarak kullanıldı. Çalıșma planı doğrultusunda hiçbir ilaç uygulaması yapılmadan tiyopental anestezisi $(70 \mathrm{mg} / \mathrm{kg}$ IP) altında uyutularak (Lukashenko ve ark. 2004) kalpten kanları alındı, sonra servikal dislokasyon yöntemi ile ötenazi edildi. Bu örneklemeden elde edilen veriler bütün gruplar için 0. (kontrol) grubu verisi olarak değerlendirildi.

Diğer gruplar ise LPS, LPS+Marbofloksasin (MAR), LPS+ Diklofenak Sodyum (DS), LPS + MetilPrednizolon (MPRED) ve LPS + Komibnasyon (KOMBİN) olmak üzere adlandırıldı. İlaç uygulamaları sonrası 1, 2, 4, 8, 12 ve 24 . saatlerde kalpten anestezi altında kanları alındı ve servikal dislokasyon yöntemi ile ötenazi uygulandı.

Deney hayvanlarına sepsis oluşturmak amaçlandığı için, deney LPS verilmesi ardından ilaç uygulaması șeklinde yapıldı. LPS $4 \mathrm{mg} / \mathrm{rat}$ dozunda serum fizyolojik (SF) ile sulandırılarak uygulandı. Marbofloksasin $100 \mathrm{mg} / \mathrm{kg}$, diklofenak sodyum $10 \mathrm{mg} / \mathrm{kg}$ ve metilprednizolon 10 $\mathrm{mg} / \mathrm{kg}$ dozda kullanıldı (Yazar ve ark. 2009).

\section{İstatistik Analiz}

Tüm grupların her bir örnekleme zamanına ait veriler OneWay Anova testi ile değerlendirildi. Önemli çlkan zamanlar/gruplar içi farkın önemliliği ise Duncan testi ile değerlendirildi (SPSS $®$ v.19 Evaluation Version for Windows, IBM).

\section{BULGULAR}

ALP düzeyinin 4 ve 12 . saatleri dıșında sadece LPS uygulanan grup ile LPS + ilaç uygulanan gruplar arasında farkın istatistiki açıdan önemli olmadığı $(P>0.05)$ belirlendi. Ayrıca 4. saatte metilprednizolon, 12. saatte ise metilprednizolon ve kombinasyon uygulamasının LPS uygulamasından farklı olduğu ve yükselen ALP seviyesini önemli ölçüde $(\mathrm{P}<0.05)$ düşürdüğü belirlendi. Her bir grubun saatler arasındaki farkına bakıldığı zaman sadece kombinasyon uygulanan grupta saatler arasında istatistiki bir fark olmadığı $(P>0.05)$, diğer gruplarda ise farklılık olduğu $(\mathrm{P}<0.05)$ gözlendi (Tablo 1$)$.

Serum AST seviyesi üzerinde, gruplar arasında 4, 12 ve 24 . saatler dıșında istatistiksel olarak fark $(\mathrm{P}<0.05)$ olmasına rağmen marbofloksasin, metilprednizolon ve kombinasyon uygulamasının LPS ile yükselen AST seviyesini düşüremediği ve istatistiksel olarak benzer olduğu $(P>0.05)$ fakat diklofenak sodyum uygulamasının 8 . saatte LPS'den farklı $(\mathrm{P}<0.05)$ olduğu ve AST düzeyini düşürdüğü belirlendi. Her bir grubun saatler arasındaki farkına bakıldığı zaman sadece diklofenak uygulanan grupta saatler arasında istatistiki bir fark olmadığ $1(\mathrm{P}>0.05)$, diğer gruplarda ise farklılık olduğu $(\mathrm{P}<0.05)$ gözlendi (Tablo 2$)$.

Serum ALT düzeyi üzerinde LPS uygulaması sonrası 8. saatte pik gözlendiği, yükselmenin 4 . saatten itibaren 24 saat boyunca devam ettiği, 4 . saatte diklofenak sodyum, 8 . saatte ise marbofloksasin ve diklofenak sodyum uygulamasının LPS'den farklı $(\mathrm{P}<0.05)$ olduğu ve serum ALT düzeyini düşürdüğü, diğerlerinin LPS'den farklı olmadığı $(P>0.05)$ belirlendi. Saatler arasında grupların karşılaştırılmasında ise sadece 4 ve 8 . saatler arasında gruplar arasında fark olduğu $(\mathrm{P}<0.05)$ diğer saatlerde ise gruplar arasında istatistiksel bir fark olmadığı belirlendi. Her bir grubun saatler arasındaki farkına bakıldığı zaman ise tüm gruplarda istatistiki olarak farklılık olduğu $(\mathrm{P}<0.05)$ gözlendi (Tablo 3$)$. 
Serum GGT düzeyinin 1. ve 2. saatte tüm gruplar arasında istatistiksel açıdan bir fark $(\mathrm{P}>0.05)$ bulunamamıștır. Metilprednizolon ile LPS uygulamaları arasinda 4. saatte fark olduğu $(\mathrm{P}<0.05)$ yükselen GGT düzeyinin düştügü, 8 . saatte marbofloksasin, metilprednizolon ve kombinasyon uygulamalarının LPS'den farklı olduğu $(\mathrm{P}<0.05)$ GGT düzeyinin düşürdüğü, 12 ve 24 . saatte ise bütün uygulamaların LPS'den farklı olduğu $(\mathrm{P}<0.05)$ ve serum GGT düzeyini düşürdükleri tespit edildi. Her bir grubun saatleri arasındaki farkına bakıldığı zaman sadece diklofenak ve kombinasyon uygulanan gruplarda saatler arasında istatistiki bir fark olmadığ ${ }_{1}(P>0.05)$, diğer gruplarda ise farklılık olduğu $(\mathrm{P}<0.05)$ gözlendi (Tablo 4).

Böbrek hasarı belirteçlerinden BUN düzeyinin LPS uygulaması sonrasında kademeli șekilde yükseldiği $(\mathrm{P}<0.05), 12$ ve 24 . saatlerde en yüksek değerine ulaştığı belirlendi. Diklofenak sodyumun LPS düzeyini diğer ilaç uygulamalarına göre 1 ve 2 . saatte düșürdüğü fakat istatistiksel olarak farklı olmadığı $(\mathrm{P}>0.05)$ gözlendi.
Dördüncü saatte metilprednizolon uygulamasının, 8. saatte kombinasyon uygulaması hariç diğer uygulamaların, 12. saatte metilprednizolon ve kombinasyon uygulamasının ve 24. saatte marbofloksasin ile metilprednizolon uygulamalarının LPS'den farklı olduğu $(\mathrm{P}<0.05)$ ve BUN düzeyini düşürdüğü tespit edildi. Her bir grubun saatler arasındaki farkına bakıldığı zaman sadece kombinasyon uygulanan grupta saatler arasında istatistiki bir fark olmadığı $(\mathrm{P}>0.05)$, diğer gruplarda ise farklılık olduğu $(\mathrm{P}<0.05)$ gözlendi (Tablo 5).

Kreatinin düzeyi incelendiğinde, diklofenak sodyum ile kombinasyon uygulamasının 1 ve 2 . saatte, 4 . saatte yalnız kombinasyon uygulamasının, 12 . saatte metilprednizolon ve kombinasyon uygulamasının, 24. saatte ise bütün uygulamaların LPS'den farklı olduğu $(\mathrm{P}<0.05)$ ve yükselen kreatinin değerini düşürdüğü belirlendi. 8. saatte ise uygulamalar arası fark olmadığı $(P>0.05)$ ve LPS uygulaması ile benzer değerlere sahip olduğu belirlendi (Tablo 6).

Tablo 1. Endotoksemik ratlarda LPS, LPS+MARBO, LPS+DS, LPS+MPRED ve LPS+KOMBİN gruplarında ALP ortalamaları ve çoklu karşılaştırma testi sonuçları (IU/L).

Table 1. Means of ALP and multiple comparison test results (IU/L) in LPS, LPS+MARBO, LPS+DS, LPS+MPRED and LPS+COMBIN groups in endotoxemic rats.

\begin{tabular}{lcccccccc}
\hline \multirow{2}{*}{ GRUPLAR } & \multicolumn{7}{c}{$\bar{X} \pm \mathbf{S} \bar{x}$} \\
\cline { 2 - 9 } & $\mathbf{0 . ~ s a a t}$ & 1. saat & 2. saat & 4. saat & 8. saat & 12. saat & 24. saat \\
\hline LPS & $132 \pm 12.5 \mathrm{w}$ & $169 \pm 26.5 \mathrm{wx}$ & $277 \pm 24.1^{\mathrm{xy}}$ & $315 \pm 25.3^{\mathrm{by}}$ & $259 \pm 42.5 \mathrm{wxy}$ & $502 \pm 67.4^{\mathrm{bz}}$ & $308 \pm 97.4 \mathrm{y}$ & $* *$ \\
LPS+MARBO & $132 \pm 12.5 \mathrm{w}$ & $121 \pm 19.9 \mathrm{w}$ & $230 \pm 13.0 \mathrm{wx}$ & $231 \pm 43.8 \mathrm{abwx}$ & $173 \pm 40.7 \mathrm{w}$ & $405 \pm 150 \mathrm{bx}$ & $179 \pm 19.8 \mathrm{w}$ & $*$ \\
LPS+DS & $132 \pm 12.5 \mathrm{w}$ & $173 \pm 11.6 \mathrm{w}$ & $216 \pm 25.7 \mathrm{w}$ & $273 \pm 84.5^{\mathrm{abwx}}$ & $202 \pm 60.0 \mathrm{w}$ & $413 \pm 81.5 \mathrm{bx}$ & $325 \pm 211 \mathrm{wx}$ & $*$ \\
LPS+MPRED & $132 \pm 12.5 \mathrm{wx}$ & $163 \pm 12.3 \mathrm{wx}$ & $312 \pm 149 \mathrm{x}$ & $169 \pm 17.2 \mathrm{awx}$ & $196 \pm 21.1 \mathrm{wx}$ & $113 \pm 11.9 \mathrm{aw}$ & $134 \pm 32.2 \mathrm{wx}$ & $*$ \\
LPS+KOMBİN & $132 \pm 12.5$ & $148 \pm 18.8$ & $157 \pm 15.2$ & $184 \pm 18.6 \mathrm{ab}$ & $142 \pm 17.7$ & $146 \pm 25.8 \mathrm{a}$ & $163 \pm 24.1$ & - \\
\hline $\mathbf{P}$ & - & - & - & $*$ & - & $*$ & -
\end{tabular}

-; $\mathrm{P}>0.05, *$; $\mathrm{P}<0.05,{ }^{* *} ; \mathrm{P}<0.01$.

a,b; Aynı sütun da gösterilen ortalamalar arasında farklılıklar önemlidir.

$\mathrm{x}, \mathrm{w}, \mathrm{y}, \mathrm{z}$; Aynı satırda gösterilen ortalamalar arasında farklılıklar önemlidir

Tablo 2. Endotoksemik ratlarda LPS, LPS+MARBO, LPS+DS, LPS+MPRED ve LPS+KOMBİN gruplarında AST ortalamaları ve çoklu karşılaştırma testi sonuçları (IU/L).

Table 2. Means of AST and multiple comparison test results (IU/L) in LPS, LPS+MARBO, LPS+DS, LPS+MPRED and LPS+COMBIN groups in endotoxemic rats.

\begin{tabular}{|c|c|c|c|c|c|c|c|c|}
\hline \multirow{2}{*}{ GRUPLAR } & \multicolumn{7}{|c|}{$\bar{X} \mathbf{\pm S} \bar{x}$} & \multirow{2}{*}{$\mathbf{P}$} \\
\hline & 0. saat & 1. saat & 2. saat & 4. saat & 8. saat & 12. saat & 24. saat & \\
\hline LPS & $148 \pm 34.1 \mathrm{wx}$ & $126 \pm 6.00 \mathrm{abw}$ & $167 \pm 23.7$ ab wx & $366 \pm 70.7 \times$ & $358 \pm 107$ bx & $92.8 \pm 92.8 \mathrm{w}$ & $173 \pm 106^{w x}$ & $*$ \\
\hline LPS+MARBO & $148 \pm 34.1 \mathrm{wx}$ & $132 \pm 18.7$ abwx & $108 \pm 11.4$ awx & $223 \pm 66.9 \times$ & $143 \pm 29.6$ abwx & $72.0 \pm 35.5 \mathrm{w}$ & $363 \pm 67.3$ у & ** \\
\hline LPS+DS & $148 \pm 34.1$ & $93.8 \pm 7.60$ a & $159 \pm 32.1 \mathrm{ab}$ & $205 \pm 32.3$ & $55.8 \pm 45.8^{a}$ & $252 \pm 157$ & $217 \pm 174$ & - \\
\hline LPS+MPRED & $148 \pm 34.1 \mathrm{w}$ & $138 \pm 12.6 \mathrm{bw}$ & $191 \pm 23.4 \mathrm{bw}$ & $242 \pm 37.5 \mathrm{wx}$ & $365 \pm 84.8$ bx & $215 \pm 25.9 \mathrm{w}$ & $173 \pm 50.4 \mathrm{w}$ & $*$ \\
\hline LPS+KOMBİN & $148 \pm 34.1 \mathrm{wx}$ & $130 \pm 16.3 \mathrm{abw}$ & $147 \pm 12.1$ abwx & $206 \pm 35.6$ wx & $272 \pm 82.4$ abwx & $307 \pm 83.3 \times$ & $246 \pm 24.9 \mathrm{wx}$ & $*$ \\
\hline $\mathbf{P}$ & - & $*$ & $*$ & - & $*$ & - & - & \\
\hline
\end{tabular}

-; $\mathrm{P}>0.05,{ }^{*} ; \mathrm{P}<0.05,{ }^{* *} ; \mathrm{P}<0.01$.

a,b; Aynı sütun da gösterilen ortalamalar arasında farklılıklar önemlidir.

$\mathrm{x}, \mathrm{w}, \mathrm{y}$; Aynı satırda gösterilen ortalamalar arasında farklılıklar önemlidir. 
Tablo 3. Endotoksemik ratlarda LPS, LPS+MARBO, LPS+DS, LPS+MPRED ve LPS+KOMBİN gruplarında ALT ortalamaları ve çoklu karşılaştırma testi sonuçları (IU/L).

Table 3. Means of ALT and multiple comparison test results (IU/L) in LPS, LPS+MARBO, LPS+DS, LPS+MPRED and LPS+COMBIN groups in endotoxemic rats.

\begin{tabular}{|c|c|c|c|c|c|c|c|c|}
\hline \multirow{2}{*}{ GRUPLAR } & \multicolumn{7}{|c|}{$\bar{X} \mathbf{\pm S} \bar{x}$} & \multirow{2}{*}{$\mathbf{P}$} \\
\hline & 0. saat & 1. saat & 2. saat & 4. saat & 8. saat & 12. saat & 24. saat & \\
\hline LPS & $43.3 \pm 9.30 \mathrm{w}$ & $40.6 \pm 5.26 \mathrm{w}$ & $81.8 \pm 13.9$ w & $227 \pm 48.7$ bwx & $380 \pm 135$ bx & $108 \pm 101$ w & $168 \pm 109 \mathrm{wx}$ & $*$ \\
\hline LPS+MARBO & $43.3 \pm 9.30 \mathrm{w}$ & $38.1 \pm 4.08 w$ & $59.8 \pm 5.07 \mathrm{w}$ & $135 \pm 41.8 \mathrm{abwx}$ & $70.5 \pm 17.2$ aw & $57.8 \pm 20.6 \mathrm{w}$ & $218 \pm 73.0 \times$ & ** \\
\hline LPS+DS & $43.3 \pm 9.30 \mathrm{w}$ & $42.3 \pm 2.72 \mathrm{w}$ & $48.6 \pm 10.2 \mathrm{w}$ & $92.0 \pm 16.5$ awx & $28.0 \pm 16.2$ aw & $300 \pm 184 x$ & $102 \pm 70.5 \mathrm{wx}$ & ** \\
\hline LPS+MPRED & $43.3 \pm 9.30 \mathrm{w}$ & $46.1 \pm 4.46 \mathrm{w}$ & $78.0 \pm 17.1 \mathrm{w}$ & $135 \pm 18.6$ abw & $259 \pm 81.1 \mathrm{abx}$ & $112 \pm 19.7 \mathrm{w}$ & $61.3 \pm 24.8 \mathrm{w}$ & $*$ \\
\hline LPS+KOMBİN & $43.3 \pm 9.30 \mathrm{w}$ & $43.1 \pm 4.82 w$ & $56.3 \pm 3.58 w x$ & $75.17 \pm 9.6$ awx & $164 \pm 82.5 \mathrm{abx}$ & $132 \pm 43.5 \mathrm{wx}$ & $137 \pm 14.6 \mathrm{wx}$ & $*$ \\
\hline $\mathbf{P}$ & - & - & - & $*$ & $*$ & - & - & \\
\hline
\end{tabular}

-; $\mathrm{P}>0.05, * ; \mathrm{P}<0.05, * * ; \mathrm{P}<0.01$.

a,b; Aynı sütun da gösterilen ortalamalar arasında farklılıklar önemlidir.

$\mathrm{x}, \mathrm{w}$; Aynı satırda gösterilen ortalamalar arasında farklılıklar önemlidir.

Tablo 4. Endotoksemik ratlarda LPS, LPS+MARBO, LPS+DS, LPS+MPRED ve LPS+KOMBİN gruplarında GGT ortalamaları ve çoklu karşılaştırma testi sonuçları (IU/L).

Table 4. Means of GGT and multiple comparison test results (IU/L) in LPS, LPS+MARBO, LPS+DS, LPS+MPRED and LPS+COMBIN groups in endotoxemic rats.

\begin{tabular}{lcccccccc}
\hline \multirow{2}{*}{ GRUPLAR } & \multicolumn{7}{c}{$\bar{X} \pm \mathbf{S} \bar{x}$} \\
\cline { 2 - 8 } & 0. saat & 1. saat & 2. saat & 4. saat & 8. saat & 12. saat & 24. saat \\
\hline LPS & $2.00 \pm 0.52^{\mathrm{w}}$ & $3.00 \pm 0.52 \mathrm{wx}$ & $7.00 \pm 1.07 \mathrm{wx}$ & $6.83 \pm 0.87 \mathrm{bwx}$ & $9.83 \pm 1.30 \mathrm{bx}$ & $30.2 \pm 4.29 \mathrm{cz}$ & $19.0 \pm 6.68 \mathrm{by}$ & $* * *$ \\
LPS+MARBO & $2.00 \pm 0.52^{\mathrm{w}}$ & $3.83 \pm 0.17 \mathrm{w}$ & $3.60 \pm 1.03 \mathrm{w}$ & $6.00 \pm 1.63 \mathrm{bw}$ & $4.33 \pm 1.05 \mathrm{aw}$ & $15.3 \pm 4.90 \mathrm{bx}$ & $3.83 \pm 0.40 \mathrm{aw}$ & $* *$ \\
LPS+DS & $2.00 \pm 0.52$ & $23.6 \pm 21.2$ & $6.00 \pm 1.00$ & $6.20 \pm 1.02 \mathrm{~b}$ & $9.17 \pm 2.50 \mathrm{~b}$ & $13.6 \pm 2.56 \mathrm{~b}$ & $9.00 \pm 9.00 \mathrm{a}$ & - \\
LPS+MPRED & $2.00 \pm 0.52^{\mathrm{w}}$ & $2.50 \pm 0.22 \mathrm{w}$ & $6.83 \pm 1.92 \mathrm{x}$ & $2.83 \pm 0.60 \mathrm{aw}$ & $3.50 \pm 0.99 \mathrm{aw}$ & $3.00 \pm 0.45 \mathrm{aw}$ & $3.50 \pm 1.23 \mathrm{aw}$ & $*$ \\
LPS+KOMBÍN & $2.00 \pm 0.52$ & $3.00 \pm 0.26$ & $4.17 \pm 0.83$ & $3.67 \pm 0.42 \mathrm{ab}$ & $2.00 \pm 0.37 \mathrm{a}$ & $3.00 \pm 1.29 \mathrm{a}$ & $2.83 \pm 0.54 \mathrm{a}$ & - \\
\hline $\mathbf{P}$ & - & - & - & $*$ & $* *$ & $* * *$ & $* *$ & \\
\hline
\end{tabular}

-; P>0.05, *; P<0.05, **; P<0.01, ***; ${ }^{*}<0.001$.

a,b,c; Aynı sütun da gösterilen ortalamalar arasında farklılıklar önemlidir.

$\mathrm{x}, \mathrm{w}, \mathrm{y}, \mathrm{z} ;$ Aynı satırda gösterilen ortalamalar arasında farklılıklar önemlidir.

Tablo 5. Endotoksemik ratlarda LPS, LPS+MARBO, LPS+DS, LPS+MPRED ve LPS+KOMBİN gruplarında BUN ortalamaları ve çoklu karşılaştırma testi sonuçları (IU/L).

Table 5. BUN averages and multiple comparison test results (IU/L) in LPS, LPS+MARBO, LPS+DS, LPS+MPRED and LPS+COMBIN groups in endotoxemic rats.

\begin{tabular}{|c|c|c|c|c|c|c|c|c|}
\hline \multirow{2}{*}{ GRUPLAR } & \multicolumn{7}{|c|}{$\bar{X} \mathbf{\pm S} \bar{x}$} & \multirow{2}{*}{$\mathbf{P}$} \\
\hline & 0. saat & 1. saat & 2. saat & 4. saat & 8. saat & 12. saat & 24. saat & \\
\hline LPS & $56.6 \pm 5.21 \mathrm{w}$ & $57.6 \pm 3.97$ abw & $64.1 \pm 7.25 \mathrm{abw}$ & $86.3 \pm 6.97 \mathrm{bw}$ & $102 \pm 12.6 \mathrm{bw}$ & $190 \pm 12.7 \mathrm{bx}$ & $190 \pm 60.2$ bx & $* * *$ \\
\hline LPS+MARBO & $56.6 \pm 5.21 \mathrm{w}$ & $71.1 \pm 3.57 \mathrm{bw}$ & $61.6 \pm 10.8 \mathrm{abw}$ & $81.0 \pm 12.7 \mathrm{abw}$ & $62.6 \pm 14.6$ aw & $140 \pm 42.5 \mathrm{abx}$ & $75.8 \pm 12.9$ aw & $*$ \\
\hline LPS+DS & $56.6 \pm 5.21 w$ & $54.3 \pm 5.30$ aw & $50.3 \pm 4.63$ aw & $73.4 \pm 12.1$ abw & $57.0 \pm 9.93$ aw & $137 \pm 23.1 \mathrm{abx}$ & $151 \pm 125 a b x$ & $* *$ \\
\hline LPS+MPRED & $56.6 \pm 5.21 \mathrm{w}$ & $67.5 \pm 1.84$ abwx & $80.0 \pm 6.60 \mathrm{bx}$ & $55.1 \pm 2.73$ aw & $54.5 \pm 3.68$ aw & $67.1 \pm 5.13$ awx & $50.6 \pm 8.94$ aw & $* *$ \\
\hline LPS+KOMBİN & $56.6 \pm 5.21$ & $72.5 \pm 7.43 \mathrm{~b}$ & $67.8 \pm 4.69 a b$ & $63.5 \pm 3.68 \mathrm{ab}$ & $73.5 \pm 5.66 \mathrm{ab}$ & $86.3 \pm 27.2$ a & $99.8 \pm 21.5 \mathrm{ab}$ & - \\
\hline $\mathbf{P}$ & - & $*$ & $*$ & $*$ & $*$ & $*$ & $*$ & \\
\hline
\end{tabular}

-; $\mathrm{P}>0.05,{ }^{*} ; \mathrm{P}<0.05,{ }^{* *} ; \mathrm{P}<0.01,{ }^{* * *} ; \mathrm{P}<0.001$.

a,b; Aynı sütun da gösterilen ortalamalar arasında farklılıklar önemlidir.

$\mathrm{x}, \mathrm{w}$; Aynı satırda gösterilen ortalamalar arasında farklılıklar önemlidir. 
Tablo 6. Endotoksemik ratlarda LPS, LPS+MARBO, LPS+DS, LPS+MPRED ve LPS+KOMBİN gruplarında kreatinin ortalamaları ve çoklu karşılaștırma testi sonuçları (IU/L).

Table 6. Creatinine mean and multiple comparison test results (IU/L) in LPS, LPS+MARBO, LPS+DS, LPS+MPRED and LPS+COMBIN groups in endotoxemic rats.

\begin{tabular}{|c|c|c|c|c|c|c|c|c|}
\hline \multirow{2}{*}{ GRUPLAR } & \multicolumn{7}{|c|}{$\bar{X}_{\mathbf{I S}} \bar{x}$} & \multirow{2}{*}{$\mathbf{P}$} \\
\hline & 0. saat & 1. saat & 2. saat & 4. saat & 8. saat & 12. saat & 24. saat & \\
\hline LPS & $0.36 \pm 0.04^{w}$ & $0.71 \pm 0.05^{\mathrm{bw}}$ & $0.63 \pm 0.07^{\mathrm{cw}}$ & $0.63 \pm 0.08^{\mathrm{bw}}$ & $0.72 \pm 0.13^{w}$ & $1.24 \pm 0.19 \mathrm{bx}$ & $1.36 \pm 0.49 \mathrm{bx}$ & $* *$ \\
\hline LPS+MARBO & $0.36 \pm 0.04 w$ & $0.71 \pm 0.05^{b w x}$ & $0.47 \pm 0.05^{\mathrm{abcwx}}$ & $0.48 \pm 0.09$ abwx & $0.49 \pm 0.09 w x$ & $0.84 \pm 0.29 \mathrm{abx}$ & $0.59 \pm 0.05^{\mathrm{awx}}$ & $*$ \\
\hline LPS+DS & $0.36 \pm 0.04 w$ & $0.45 \pm 0.03 \mathrm{aw}$ & $0.41 \pm 0.07 \mathrm{abw}$ & $0.45 \pm 0.03 \mathrm{abw}$ & $0.55 \pm 0.14 \mathrm{w}$ & $0.98 \pm 0.19 a \mathrm{abx}$ & $0.43 \pm 0.37$ aw & $* *$ \\
\hline LPS+MPRED & $0.36 \pm 0.04 w$ & $0.67 \pm 0.01$ by & $0.56 \pm 0.06$ bcxy & $0.45 \pm 0.02 \mathrm{abwx}$ & $0.61 \pm 0.03 x y$ & $0.51 \pm 0.06$ awxy & $0.45 \pm 0.10 \mathrm{awx}$ & $* *$ \\
\hline LPS+KOMBİN & $0.36 \pm 0.04 w$ & $0.52 \pm 0.02$ ax & $0.35 \pm 0.01$ aw & $0.36 \pm 0.01$ aw & $0.54 \pm 0.06^{\mathrm{x}}$ & $0.55 \pm 0.09$ ax & $0.66 \pm 0.05$ ax & $* * *$ \\
\hline $\mathbf{P}$ & - & $* * *$ & $* *$ & $*$ & - & $*$ & $*$ & \\
\hline
\end{tabular}

-; $\mathrm{P}>0.05, *$; $\mathrm{P}<0.05, * * ; \mathrm{P}<0.01, * * * ; \mathrm{P}<0.001$.

a,b,c; Aynı sütun da gösterilen ortalamalar arasında farklılıklar önemlidir.

$\mathrm{x}, \mathrm{w}, \mathrm{y}$; Aynı satırda gösterilen ortalamalar arasında farklılıklar önemlidir.

\section{TARTIŞMA VE SONUÇ}

Sepsis ve septik şok olguları hem veteriner sahada hem de beşerî hekimlik alanında önde gelen mortalite nedeni olmaya devam etmektedir. Sepsis; patogenezi gram-negatif ve gram-pozitif bakteriler ve mantarlar ya da her ikisinin de şiddetlenen inflamatuvar yanıtı ile enfeksiyonun bir arada olduğu durumdur. Sepsis ile yapılan büyük mücadelelere rağmen, dünya çapında yılda 8 milyon ölüm gözlenmektedir (Dawulieti ve ark. 2020; Prauchner 2020).

Organizmanın immünolojik savunma mekanizmalarında çok önemli rol oynadığı için sepsis durumunda en çok etkilenen organın karaciğer olduğu düşünülmektedir (Pastor ve ark. 1995; James ve ark. 2002). AST tüm hayvanlarda yumuşak doku nekrozunun nonspesifik indikatörüdür. Serum ALT'nin en spesifik aktivitesi karaciğerdedir. $\mathrm{Bu}$ nedenle karaciğer hasarı belirteci olarak kullanılır. Köpek ve kedilerde karaciğer hasarının teşhisinde ALT spesifik bir değerdir. ALT karaciğer hasarında AST'den daha fazla yükselir. Özellikle akut hepatit ve steroid hepatopatisinde miktarı artar. Karaciğer hasarı meydana geldiğinde artan diğer bir enzim ise GGT'dir. İnsanlarda hepatik siroz, hepatik karsinomda GGT miktarı yükselir. ALP testi genelde safra salgısı bozukluklarında, safra yolları tıkanıklıklarında, karaciğer hastalıklarında kullanılan bir parametredir. ALP, vücutta en fazla bulunan enzimlerden biridir. Serum ALP aktivitesi septisemi ve endotoksemide, karaciğer hasarı nedeni ile normal üst sınırın birkaç katı yükselebilir (Turgut 2000; Kerr 2002; Swarnalatha ve ark. 2020).

Deneysel sepsis/septik şok modellerinde ve gerçek hastalarda yapılan araştırmalarda, genellikle bir ilaç için, bir veya birkaç doz örneklemesi yapılmaktadır. Gerçek hastalarda yapılan incelemelerde ise kontrol gruplarının farklılığı bir diğer problemi oluşturmaktadır. Ayrıca septik şokun ilk ve son dönemi ile ölen veya yaşayan hastalarda kan parametrelerinde çok farklı sonuçlar elde edildiği bildirilmektedir (Yazar ve ark. 2009). Bu araştırmada 24 saat süresince aralıklı kan alınarak (1 - 2 - 4 - 8 - 12 ve 24 . saatlerde) organ hasarı belirteçleri incelenmiştir.

Karaciğer yetmezliğinin sepsiste erken dönemde oluştuğu ve LPS uygulaması sonucu serum aminotrasferazlarda artışlar ile karaciğer hasarına neden olduğu bildirilmektedir (Berger ve Chiolero 2007). Yazar ve ark.
(2009; 2010)'nın yaptıkları çalışmalarda LPS uygulaması sonrası karaciğer enzimlerinde belirgin düzeyde artış bildirilmiştir. LPS uygulamasının tavşan (Elmas ve ark. 2006; Elmas ve ark. 2008) ve ratlarda (Yazar ve ark. 2004) serum AST, ALT ve GGT düzeyini artırdığı bildirilmiștir. Yapılan çalışmada da karaciğer hasarı belirteçleri olan serum AST, ALT, GGT ve safra kanalı hasarı belirteci olan serum ALP düzeyleri değerlendirildiğinde, adı geçen parametrelerin LPS uygulaması ile arttığı $(\mathrm{P}<0.05)$ ve sepsiste beklenilen etkinin şekillendiği tespit edildi. $\mathrm{Bu}$ sonuçlar yapılan diğer çalışmalar (Yazar ve ark. 2004; Elmas ve ark. 2006) ile paralellik göstermektedir. Sonuçlar aynı zamanda LPS uygulaması ile karaciğer ve safra kanalı hasarının oluştuğunu da göstermektedir.

Tavşanlarda LPS uygulaması sonrasında yükselen ALT düzeyinin, prednizolon uygulanması ile engellendiği belirlenmiştir (Yazar ve ark. 2004). Mevcut çalışmada gelișen karaciğer ve safra kanalı hasarını önlemede, incelenen tüm karaciğer enzimleri ve serum ALP düzeyi dikkate alındığında, metilprednizolon ve kombinasyon uygulamasının başarılı olduğu ve sağlıklı bireyler kadar olmasa da olumlu sonuçlar verdiği tespit edildi. ALT düzeyi ölçümünde metilprednizolon uygulaması ile 4,8 ve 12 . saatlerde yükselme tespit edildi. $\mathrm{Bu}$ yükselmenin metilprednizolon uygulamasına bağlı olarak şekillenebilecek steroid hepatopatiden kaynaklabileneceği düşünülmektedir. Metilprednizolon ve kombinasyon uygulamasının yükselen karaciğer enzimlerini düşürmede etkili olmasındaki nedenin karaciğerde Serbest Oksijen Radikalleri (SOR) ve sitokin üretimine engel olabilmesinden kaynaklandığı düşünülmektedir.

Sepsis vb durumlarda serum üre (veya kan üre azotu) ve kreatinin artışları yaygındır ve kreatinin konsantrasyonunda küçük bir artış bile kritik hastalığı olan hastalarda daha kötü sonuçlarla ilişkilidir (Lelubre ve Vincent 2018). Böbrek hasarı belirteçleri serum BUN ve kreatinin düzeyinin LPS uygulanan laboratuvar hayvanlarında yükseldiği bildirilmiştir (Wang ve ark. 2004; Yazar ve ark. 2004; Wedn ve ark. 2020). Üre, nitrojen amonyak metabolizmasının son ürünü olarak, kreatinin ise kreatin fosfatın nonenzimatik parçalanması sonrası son ürün olarak kana geçer. BUN düzeyinin kedilerde ve bazı atlarda $15 \mathrm{mmol} /$ L'ye kadar yükseldiği, BUN için üst sınırın $30 \mathrm{mg} / \mathrm{dL}$, kreatinin için ise üst sınırın $2 \mathrm{mg} / \mathrm{dL}$ olabileceği bildirilmiștir (Turgut 2000; Kerr 
2002). Yazar ve ark. (2009)'nın yaptığı çalıșmada fluniksin meglumin uygulamasının LPS uygulanan ratlarda yükselen BUN seviyesini değiştiremediği, dekzametazonun ise tek bașına ve kombine uygulamada etkili olarak BUN düzeyini yükseltmeye engel olduğu bildirilmektedir.

Mevcut çalışmada LPS uygulanmasının ardından dereceli bir BUN yükselmesi gözlendi. Serum BUN düzeyi 12 ve 24 . saatlerde maksimum seviyesine ulaştı. 12. saatte yükselen BUN seviyesini metilprednizolon uygulamasının düșürdüğü $(\mathrm{P}<0.05), 24$. saatte ise metilprednizolon ve marbofloksasin uygulamasının etkili olduğu ve BUN seviyesini düşürdüğü $(\mathrm{P}<0.05)$ belirlendi. Çalışmada kreatinin düzeyi LPS uygulamasının 24. saatinde sağlıklı bireylere oranla 4 kat ve üzerinde yükseldi. LPS uygulaması ile yükselen kreatinin düzeyini 24. saatte bütün uygulamaların düşürdüğü $(\mathrm{P}<0.05)$ belirlendi. Ancak kreatinin ilk saatleri göz önüne alındığında LPS'den kombinasyon uygulaması dișında diğer uygulamaların farkının olmadığı $(P>0.05)$ gözlendi. Metilprednizolon'un böbrek hasarı üzerindeki etkisinin yine karaciğer üzerindeki etkisinde olduğu gibi SOR ve sitokin üretimine engel olmasına bağlı olduğu düşünüldü.

Sonuç olarak, LPS ile deneysel endotoksemi şekillendirilen bu araștırmada doğal olarak şekillenen sepsise benzer biyokimyasal bulgular elde edildi. Bu sonuçlara bağlı olarak IP yolla enjekte edilen marbofloksasin ile diklofenak sodyum uygulamaların tek başlarına sepsis tedavisinde etkisinin olmadığı belirlendi. Metilprednizolon uygulamasının sepsiste etkili olabileceği ancak tek başına kullanılamayacağı kanaatine varıldı Kombinasyon uygulamasının \%100 tedavi sağlamasa da etkisinin göz ardı edilmeyecek derecede iyi olduğu ve sepsis ile septik şok olgularında kullanım alanı bulabileceği sonucuna ulaşıldı.

\section{ÇIKAR ÇATIŞMASI}

Yazarlar bu çalışma için herhangi bir çıkar çatışması olmadığını beyan ederler.

\section{TEŞEKKÜR VE BİLGİLENDİRME}

$\mathrm{Bu}$ araştırma Van Yüzüncü Yıl Üniversitesi Bilimsel Araștırma Projeleri Bașkanlığı tarafından 2010-SBE-D174 no'lu proje ile desteklenmiştir. Bu çalıșma Ahmet Cihat ÖNER isimli yazarın doktora tezinden elde edilen veriler ile gerçekleştirilmiş olup "IV. Ulusal Veteriner Farmakoloji ve Toksikoloji Kongresi" isimli kongrede poster sunu olarak sunulmuş, kongre kitabına özet metin olarak basılmıștır.

\section{YAZAR KATKILARI}

Fikir/Kavram: ACÖ

Denetleme/Danışmanlık: AŞ

Veri Toplama ve/veya İşleme: ACÖ

Analiz ve/veya Yorum: ACÖ

Makalenin Yazımı: ACÖ, AȘ

Eleştirel İnceleme: AŞ

\section{KAYNAKLAR}

Berger MM, Chiolero RL (2007). Antioxidant supplementation in sepsis and systemic inflammatory response syndrome. Crit Care Med, 35, 584590.
Bonelli F, Meucci V, Divers TJ, Boccardo A, Pravettoni D ve ark. (2018). Plasma procalcitonin concentration in healthy calves and those with septic systemic inflammatory response syndrome. Vet J, 234, 61-65.

Boscolo P, Youinou P, Theoharides TC, Cerulli G, Conti P (2008). Environmental and occupational stress and autoimmunity. Autoimmun Rev, 7, 340-343.

Camcioğlu Y, Aytaç E (2007). Sepsisin İmmunopatogenezi. Türk Yoğun Bakım Dergisi, 5, 81-85.

Constable PD, Kenneth W, Hinchcliff KW, Done SH, Grünberg W (2017) Veterinary Medicine. A Textbook of the Diseases of Cattle, Sheep, Pigs, Goats and Horses. 11th ed., Saunders, Missouri.

Dawulieti J, Sun M, Zhao Y, Shao D, Yan H, et all (2020). Treatment of severe sepsis with nanoparticulate cell-free DNA scavengers, Sci Adv, 6 , 7148.

Elmas M, Yazar E, Uney K, Er Karabacak A (2006). Influence of Escherichia coli endotoxin induced endotoxaemia on the pharmacokinetics on enrofloxacin after intravenous administration in rabbits. J Vet Med A, 53, 410-414.

Elmas M, Yazar E, Uney $K$, Er Karabacak A, Tras B (2008) Pharmacokinetics of enrofloxacin and flunixin meglumine and interactions between both drugs after intravenous co-administration in healthy and endotoxaemic rabbits. Vet J, 177, 418-424.

Hart KA, MacKay RJ (2015). Endotoxemia and sepsis. In: Smith BP (Editor). Large Animal Internal Medicine (pp.682-695). 5th Edition, St.Louis, Missouri: Elsevier.

James PE, Madhani M, Roebuck W, Jackson SK, Swartz HM (2002). Endotoxin-induced liver hypoxia: Defective oxygen delivery versus oxygen consumption. Nitric Oxide, 6, 18-28.

Kerr MG (2002). İndividual enzyme interpretation (pp.101-147). Veterinary Laboratuary Medicine, Blackwell Science, 2th edit.

Lelubre C, Vincent JL (2018). Mechanisms and treatment of organ failure in sepsis. Nat Rev Nephrol, 14 (7), 417-27.

Lukashenko PV, Lukashenko TM, Savanovich II, Sandakov DB, Gerein V (2004). Granulocyte macrophage colony-stimulating factor regulates activity of the nervous system. Neuroimmunomodulation, 11, 36-40.

Meduri GU (1999). An historical review of glucocorticoid treatment in sepsis. Disease pathophysiology and the design of treatment investigation. Sepsis, 3, 21-38.

Minneci PC, Deans KJ, Banks SM, Eichacker PQ, Natanson C (2004) Meta-Analysis: The effect of steroids on survival and shock during sepsis depends on the dose. Ann Intern Med, 141 (1), 47-58.

Pardon B, Deprez P (2018). Rational antimicrobial therapy for sepsis in cattle in face of the new legislation on critically important antimicrobials. Vlaams Diergen Tijds, 87, 37-46.

Pastor CM, Billiar TR, Losser MR, Payen DM (1995). Liver injury during sepsis. J Crit Care Med, 10, 183-197.

Prauchner CA (2017). Oxidative stress in sepsis: Pathophysiologicalimplications justifying antioxidant co-therapy, Burns, 43, 471-485.

Swarnalatha Y, Sivakkumar SU, Siddharthan S (2020). Protective role of heptamethoxyflavone on LPS-induced hepatotoxicity. Toxin Reviews.

Traş B, Yazar E, Elmas M (2007). Veteriner Hekimliğinde İlaç Kullanımına Pratik ve Akılcı Yaklaşım. Olgun Çelik Ofset Matbaası, Konya.

Turgut K (2000). Veteriner Klinik Laboratuvar Teşhis. Bahçıvanlar A.Ş, Konya.

Wedn AM, El-Gowilly SM, El-Mas MM (2020). Time and sex dependency of hemodynamic, renal, and survivability effects of endotoxemia in rats. Saudi Pharmaceutical Journal, 28, 127-135.

Wang CC, Lee YM, Wei HP, Chu CC, Yen MH (2004). Dextromethorphan prevents circulatory failure in rats with endotoxemia. J Biomed Sci, 11, 739-747.

Yarema TC, Yost $S$ (2011). Low-Dose Corticosteroids to Treat Septic Shock: A Critical Literature Review. Crit Care Nurse, 31, 16-26.

Yazar E, Cöl R, Konyalıoğlu S ve ark. (2004). Effects of vitamin E and prednisolone on biochemical and haematological parameters in endotoxemic New Zealand white rabbits. B Vet I Pulawy, 48, 105-108.

Yazar E, Elmas M, Traș B, Üney K, Er A (2009). Septik şok tedavisinde kullanılan ilaçların şokun patofizyolojisine etkileri. Tübitak Projesi, Proje No: 1070042

Yazar E, Er A, Uney K, Bulbul A, Avcı GB ve ark. (2010). Effects of drugs used in endotoxic shock on oxidative stress and organ damage markers. Free Rad Res, 44, 397-402. 